\title{
EHMTI-0138. Significance of neurovascular contact in classical trigeminal neuralgia
}

\author{
S Maarbjerg ${ }^{1 *}$, F Wolfram², A Gozalov¹, J Olesen ${ }^{1}$, L Bendtsen ${ }^{1}$ \\ From 4th European Headache and Migraine Trust International Congress: EHMTIC 2014 \\ Copenhagen, Denmark. 18-21 September 2014
}

\begin{abstract}
Introduction
Neurovascular contact (NVC) is considered a frequent cause of classical trigeminal neuralgia (TN) and transposition of a blood vessel in the potentially dangerous procedure of microvascular decompression is considered over other surgical options in medically refractory TN. However, prevalence of NVC has not been investigated in a representative neurological TN patient cohort using highquality imaging and blinded evaluator.
\end{abstract}

\section{Aim}

We aimed to investigate whether presence and degree of NVC are correlated to pain side in TN.

\section{Methods}

Consecutive TN patients were referred to 3.0 Tesla MRI and included in a cross-sectional study. MRI scans were evaluated blindly and graded according to presence and degree of NVC. Severe NVC was defined as displacement or atrophy of the trigeminal nerve.

\section{Results}

A total of $135 \mathrm{TN}$ patients were included. NVC in general was prevalent on both symptomatic and asymptomatic side $(89 \%$ vs. $78 \%, \mathrm{p}=0.014$, $\mathrm{OR}=2.4(1.2-4.8), \mathrm{p}=0.017)$ while severe NVC was highly prevalent on symptomatic compared to asymptomatic side (53\% vs. $13 \%$, p $<0.001$, OR $=11.6$ (4.7-28.9), $\mathrm{p}<0.001)$. Severe NVC was caused by arteries in $98 \%$.

\section{Conclusions}

Severe NVC is associated to pain side in TN, while any type of NVC is common on both symptomatic and asymptomatic side. Findings demonstrate importance of NVC

1Danish Headache Center Department of Neurology, Glostrup Hospital University of Copenhagen, Glostrup, Denmark

Full list of author information is available at the end of the article grading and have important implications for understanding of TN etiology and most likely for patient selection for microvascular decompression.

No conflict of interest.

\section{Authors' details}

'Danish Headache Center Department of Neurology, Glostrup Hospital University of Copenhagen, Glostrup, Denmark. ${ }^{2}$ Department of Diagnostics, Glostrup Hospital University of Copenhagen, Glostrup, Denmark.

Published: 18 September 2014

doi:10.1186/1129-2377-15-S1-C39

Cite this article as: Maarbjerg et al: EHMTI-0138. Significance of neurovascular contact in classical trigeminal neuralgia. The Journal of Headache and Pain 2014 15(Suppl 1):C39.

\section{SpringerOpen ${ }^{\circ}$}

(c) 2014 Maarbjerg et al; licensee Springer. This is an Open Access article distributed under the terms of the Creative Commons Attribution License (http://creativecommons.org/licenses/by/2.0), which permits unrestricted use, distribution, and reproduction in any medium, provided the original work is properly cited.
Submit your manuscript to a SpringerOpen ${ }^{\circ}$ journal and benefit from:

- Convenient online submission

- Rigorous peer review

- Immediate publication on acceptance

- Open access: articles freely available online

- High visibility within the field

- Retaining the copyright to your article

Submit your next manuscript at $>$ springeropen.com 